\title{
Diagnosis of Hypoglycemia due to Over-Dosage of Insulin Analog, Insulin Lispro
}

\author{
Hidetaka Hamasaki ${ }^{\mathrm{a}, \mathrm{c}}$, Hidekatsu Yanai ${ }^{\mathrm{a}, \mathrm{b}, \mathrm{c}, \mathrm{d}}$
}

\section{To the Editor:}

Serum insulin assay is used for the diagnosis of diabetes and hypoglycemia and is also used to quantify insulin for insulin pharmacokinetic evaluations. Serum C-peptide is usually measured in subjects who use insulin for evaluation of intrinsic insulin secretion. We experienced a hypoglycemic diabetic patient treated by premixed insulin lispro $75 / 25$ (75\% insulin lispro protamine suspension and 25\% insulin lispro) who showed undetected serum levels of both insulin and Cpeptide.

A 74-year-old type 2 diabetic man has been treated by injection of 26 units of premixed insulin lispro 75/25 before breakfast. In December 2010, his food intake decreased due to appetite loss, however, he injected 26 units of premixed insulin lispro $75 / 25$, and subsequently developed disturbance of consciousness. He was admitted to our department, and his blood glucose level was $37 \mathrm{mg} / \mathrm{dL}$. His consciousness promptly recovered after intravenous injection of glucose, and then he has been diagnosed as having hypoglycemia. We expected that his serum insulin level is high. However,

Manuscript accepted for publication April 6, 2012

\footnotetext{
${ }^{\mathrm{a}}$ Department of Internal Medicine, National Center for Global Health and Medicine, Kohnodai Hospital, Chiba 272-8516, Japan

${ }^{\mathrm{b}}$ Clinical Research Center, National Center for Global Health and Medicine, Kohnodai Hospital, Chiba 272-8516, Japan

${ }^{c}$ Hidetaka Hamasaki and Hidekatsu Yanai contributed equally to this study.

${ }^{\mathrm{d}}$ Corresponding author: Hidekatsu Yanai, Department of Internal Medicine, National Center for Global Health and Medicine, Kohnodai Hospital, 1-7-1 Kohnodai, Chiba 272-8516, Japan.

Email: dyanai@hospk.ncgm.go.jp
}

doi:10.4021/jem92w serum insulin and also C-peptide were not detected. HbAlc is $5.5 \%$, and anti-glutamic acid decarboxylase antibody was negative, and ${ }^{125} \mathrm{I}$-insulin binding rate was not too high $(2.6 \%)$. His urinary C-peptide level was very low $(4.0 \mu \mathrm{g} /$ day; normal range, $29.2-167.0 \mu \mathrm{g} /$ day), suggesting the presence of severely decreased insulin secretion capacity. What is the cause of his hypoglycemia?

Insulin analogs that are prepared with recombinant DNA technology are available for clinical use. One obvious question with insulin analogs is whether they are detectable by immunoassay. Serum insulin could not be detected by the chemiluminescent enzyme immunoassay (CLEIA) using Lumipulse Presto Insulin (Fuji Rebio, Tokyo, Japan) in our patient (Table 1). However, serum insulin could be measured by radioimmunoassay (RIA) using Insulin Eiken (Eiken Chemical Company, Tokyo, Japan). Lumipulse Presto Insulin could detect NPH human insulin, but, could not detect insulin lispro, and showed very low cross-reactivity with premixed insulin lispro 75/25 (Table 1). Insulin Eiken showed a high cross-reactivity with NPH human insulin, insulin lispro and premixed insulin lispro 75/25 (Table 1).

Insulin lispro is a human insulin analog created by reversing the amino acids at positions 28 (Pro to Lys) and 29 (Lys to Pro) of the B chain of human insulin [1]. A sensitive RIA that is specific for insulin lispro has been developed [2]. Further, the combination of insulin assays that detect human insulin only or both human insulin and insulin analogs provides a new tool for studying pharmacokinetics of insulin lispro [3]. However, all of these assays are used mainly for research and are not usually used in clinical laboratories. Owen WE, et al studied cross-reactivity of insulin analogs with commercial insulin immunoassays [4]. Insulin lispro had a high cross-reactivity of $80 \%$ and $90 \%$ with the Access analyzer (Beckman Coulter) and the Advia Centaur analyzer (Bayer Diagnostics), respectively, whereas insulin lispro had a low cross-reactivity of $43 \%$ and $28 \%$ with the Coat-ACount (Diagnostic Products Corporation) and the IMMULITE 2000 analyzer (Diagnostics Products Corporation), respectively. The E170 method did not detect insulin lispro, indicating that the antibody used in this assay could not recognize an epitope that includes B28 and/or B29 of the $\mathrm{B}$ chain. The antibody in the assay of Lumipulse Presto Insu- 
Table 1. Insulin Levels in Patient's Sera, Premixed Insulin Lispro 75/25, Insulin Lispro and NPH Human Insulin, Measured by Lumipulse Presto Insulin and Insulin Eiken Assay

\begin{tabular}{lll}
\hline & $\begin{array}{l}\text { Lumipulse Presto Insulin } \\
(\text { CLEIA, } \mu \mathrm{U} / \mathrm{ml})\end{array}$ & $\begin{array}{l}\text { Insulin Eiken } \\
(\mathrm{RIA}, \mu \mathrm{U} / \mathrm{ml})\end{array}$ \\
\hline Patient's sera & $<0.3$ & 33 \\
$\begin{array}{l}\text { Insulin lispro mix } 75 / 25 \\
\left(1 \times 10^{-2} \text { unit }\right)\end{array}$ & 2.11 & $5.2 \times 10^{6}$ \\
$\begin{array}{l}\text { Insulin lispro } \\
\left(1 \times 10^{-2} \text { unit }\right)\end{array}$ & $<0.3$ & $5.4 \times 10^{6}$ \\
$\begin{array}{l}\mathrm{NPH} \text { human insulin } \\
\left(1 \times 10^{-2} \text { unit }\right)\end{array}$ & 285 & $4.3 \times 10^{6}$ \\
\hline
\end{tabular}

CLEIA: chemiluminescent enzyme immunoassay; premixed insulin lispro $75 / 25,75 \%$ insulin lispro protamine suspension and $25 \%$ lispro; $\mathrm{RIA}$, radioimmunoassay.

lin which we used for our patient may have similar structure to the antibody in the E170 assay. It seems plausible that the antibody used in the assay of Insulin Eiken recognizes an epitope that includes other parts of insulin except for B28 and/or B29 of the B chain. Recent study in Japan reported that the ARCHITECT insulin assay (Abbott Laborotories), a chemiluminescent immunoassay showed a significantly high cross-reactivity of $100 \%$ with insulin lispro as well as E-test TOSOH II (TOSOH Corporation), RIA [5].

In conclusion, the large variability in insulin lispro cross-reactivity with different commercial assays is noteworthy. It is very important for clinicians to be aware of the cross-reactivities of various insulin analogs with the assays used in clinical laboratories. Further, clinicians also should choose the most suitable immunoassay to examine hypoglycemic patients due to over-dosage of insulin analogs.

\section{Acknowledgment}

This work was supported by the Grant of National Center for Global Health and Medicine (22-120).

\section{References}

1. Howey DC, Bowsher RR, Brunelle RL, Woodworth JR. [Lys(B28), Pro(B29)]-human insulin. A rapidly absorbed analogue of human insulin. Diabetes. 1994;43(3):396402.

2. Bowsher RR, Lynch RA, Brown-Augsburger P, Santa PF, Legan WE, Woodworth JR, Chance RE. Sensitive RIA for the specific determination of insulin lispro. Clin Chem. 1999;45(1):104-110.

3. Lindstrom T, Hedman CA, Arnqvist HJ. Use of a novel double-antibody technique to describe the pharmacokinetics of rapid-acting insulin analogs. Diabetes Care. 2002;25(6):1049-1054.

4. Owen WE, Roberts WL. Cross-reactivity of three recombinant insulin analogs with five commercial insulin immunoassays. Clin Chem. 2004;50(1):257-259.

5. Moriyama M, Hayashi N, Ohyabu C, Mukai M, Kawano S, Kumagai S. Performance evaluation and cross-reactivity from insulin analogs with the ARCHITECT insulin assay. Clin Chem. 2006;52(7):1423-1426. 